JournEEL

ISSN 2721-611X Vol. 3. No. 1, June 2021, Page. 55-64

\title{
The Psychological Dynamics Underlying of Criminal Theft Accompanied by Violence
}

\author{
Agung Himawan \\ Universitas 17 Agustus 1945 Surabaya, Email: agunghimawan_s2@untag-sby.ac.id
}

\section{Suryanto}

Universitas Airlangga Surabaya, Email: suryanto@psikologi.unair.ac.id

Niken Titi Pratitis

Universitas 17 Agustus 1945 Surabaya, Email: nikenpratitis@ untag-sby.ac.id

\begin{abstract}
This study was aimed to describe the forms of aggressive behavior by the perpetrator of the crime of theft which is accompanied by violence and the factors that cause the perpetrator to commit theft accompanied by violence. The method used in this research is a qualitative research method with a phenomenological approach by using observation and interview data collection techniques. The data analysis technique consists of the following stages: analyzing all data, categorizing data, compiling psychological dynamics, connecting with theoretical foundations, and drawing conclusions. Based on the results of the study, it is concluded that the forms of aggressive behavior committed by the perpetrators of criminal acts of theft accompanied by violence are verbal or symbolic aggression, namely in the form of harsh words, threatening, and cursing and physical aggressive behavior, namely: physical assault in the form of forcibly taking or confiscating the victim's property, hitting, injuring and injuring the victim using a sharp weapon.
\end{abstract}

Keywords: aggressive behavior, perpetrator, crime, violence, phenomenology

\section{INTRODUCTION}

Violence is part of aggressive behavior. Violence is one of the aggressive types that pointed to extreme of physical aggression. Violence is defined as intensive pressure to people or property with the aim of damaging, punishing or controlling. This aggressive behavior can cause a person, especially men, to commit acts of violence against the victim. Whittaker (in Sagala, 2008) said that aggressive behavior is often used to indicate a tendency to attack other people or individuals who have the intention to cause physical or psychological injury, thus excessive physical action, criticism and use of harsh verbal language are also aggressive behavior. It is implied that aggressive behavior is a negative form of behavior that arises from stimulation, especially stimuli from the environment, which often results in a greater impact. Aggressive behavior can be both physical and verbal and can occur to other people or objects that are target of aggressive behavior. 
Many figures explain the concept of aggressive behavior, according to Baron (in Koeswara, 1988) aggressive is individual behavior aimed at injuring or harming others who do not want the behavior to come. Additionally, Aronson (in Koeswara, 1988) explains that aggressive is behavior carried out by the individuals with the intention of hurting or harming others with or without a particular purpose. Meanwhile, Moore and Fine (in Koeswara, 1988) defined aggression as either physically or verbally violent behavior toward other individuals or against objects. While Berkowitz (in Krahe, 2005) defines aggressive in terms of violating norms or socially unacceptable behavior, which means ignoring the problem that normative evaluation of behaviors is often different, depending on the perspective of the individuals involved. Violence is a form of being aggressive behavior that causes suffering or hurt others, and there is a difference between aggressive as a form of thought and feeling and being aggressive as a form of behavior (Adi, 2009). Aggressive is a response to anger, disappointment, feelings of revenge, or threats that provoke anger which can generate violent behavior in a way of resisting or punishing in the form of attacking, damaging, or killing (Adi, 2009). According to Atkinson (2001) there are several types of aggressive as follows:

A. An Aggressive Instrumental, aggressive aimed at causing suffering to its victim by using tools, either objects or people or ideas that can be used to manifest their aggressive feelings, for example, people attack or injure others by using an object or tool to make another suffer.

B. Verbal Aggressiveness, aggressiveness that is done to the source of verbal aggression. Verbal aggressive may be words of ill will or words that are thought to be capable of inflicting pain, injuring, offending, or causing others to suffer.

C. A Physical Aggressiveness, physical aggression in an act of anger by the individual experiencing this aggression, for example being aggressive in a fight, an offensive response to a broad stimulus of both living and dead objects.

D. An Emotional Aggression, aggression performed solely as an act of anger and aggression is often experienced by people who cannot have the ability to openly aggressively, for example because of limited abilities, weakness, and helplessness. This aggressiveness is aroused by feelings of offense or anger, yet this aggressiveness is only as desires (hidden in nature), for example, an individual will feel hurt if other individual do not respect himself directly, as people who hold other people's heads, people who hold their heads will feel offended.

E. A Conceptual Aggressiveness, aggressiveness which is also expressing aggressively caused by the inability to fight both verbally and physically. Angry individuals express their aggressiveness in the form of concepts or Suggestions that make others become 
aggressive, for example, forms of sedition, misguided ideas, or issues that cause others to become angry, upset, disappointed or suffer.

As it is argued by several theories, there are several factors causing of aggression that can be described as follows:

\section{A. Social Factors}

1. Frustrated. Frustration can be a powerful trigger for aggression. This happens under certain conditions (Barron, 2003). This particular condition, for example, is the continuous pressure from the environment. When the pressure comes to causes frustration then the tendency to behave aggressively is greater than usual.

2. The Direct Provocation. The direct provocation from others is a powerful trigger of aggression. Rarely do we yield; in fact, it tries to equalize - or slightly exceed - the aggressive levels we receive from others (Barron, 20003). When it comes to direct provocation first, the tendency to behave aggressively also increases. An example is a brawl that occurs between football audiences as a result of mutual ridicule. This mutual ridicule is a form of direct provocation that ultimately results in aggressive behavior in the form of brawls.

3. Exposure to Violence. This happens in the mass media that is found increase aggressiveness among the audience. This occurs due to several factors, such as the initial exposure to aggressive thinking and the weakened defenses to refuse to be aggressive (Barron, 2003). The media scenes, both print or electronic, can never be separated from people's lives. One of them is a television. From the 240 million population in Indonesia, Nielsen surveyed urban communities in 10 cities (Jakarta, Surabaya, Medan, Semarang, Bandung, Makassar, Palembang, Yogyakarta, and Banjarmasin). It turns out that 94 percent of people spent about five and a half hours per day watching television (Rofiq, 2013). If the content on the television shows aggressive behavior, it will tend to make the society imitate it.

4. Increase Stimulation of Retention. It could increase aggression if the stimulation persists after passing through where it occurs and is misinterpreted as an anger (Barron, 2003). As continuously increase external stimulation will trigger aggressive behavior.

\section{B. Personal Factors}

1. Type A Behavior Patterns. The individual with the type A personality is a human being who constantly want to achieve something higher (high and many), with less time at all times (Kreitner \& Kinicki, 2005). People who exhibit Type A behavior patterns are 
more irritable and more aggressive (Barron, 2003). Friedman \& Rosenman (Gibson, 1996) states that individuals who identify the A type of personality tend to be aggressive and ambitious. Their attitude is easy to appear vague, impatient, competitive, and their mind is constantly full of problems in their work. Thus, the individuals with type A behavior patterns are those who always want more, are irritable, aggressive, ambitious, impatient, competitive and their minds are always filled with problems in their work.

2. Hostile Attributional Bias. Hostile Attributional Bias is the tendency to perceive the intentions or motives of hatred in other people when the action is considered ambiguous (Barron, 20003). An example of when Susi crashed by Rudi, then Rudi trying to apologize yet due to Susi's feeling that Rudi hit her as a form of hatred, Susi will remain angry at Rudi. Barron (2003) also states individuals who have a bias attributional hostile that high attribute the actions of others on the mean hostie/hate. As a result, they become more aggressive than people who have low levels in these characteristics.

3. Gender. Barron (2003) noted that men are generally more aggressive rather than women, yet this difference is reduced in the context of the strong provocation. Men are more likely to use a direct form of aggression, yet women are more likely to use an indirect form of aggression. Men are more likely to engage in a forced sex than women.

\section{Situational Factors}

Barron (2003) stated that situational factors can cause aggressive behavior are the high air temperature and alcohol. High temperatures tend to increase aggressively, yet only up to a certain point. The aggressively decreases while the temperature of the air increases. Alcohol consumption can increase aggression - especially seems on the individuals in the normal state indicates the level of low aggression. Aggressive carried out successively in the long term, especially when if it occurs in children or since childhood, may have an impact on the development of their personality (Fox \& Gilbert, in Sarwono 2011). For example, a person who in his childhood experienced physical and/or sexual treatment, in adulthood he might become depressive, have a low self-esteem, and often become depressed.

According to research conducted by Fitriani (2012) aggressive behavior have two impacts, internal and external. The internal impacts such as personal satisfaction, the repetition of similar behavior, the feeling of guilt towards the family, the decreased of interest in learning, and receiving punishment as well as penalties or sanctions. While the external impacts are: 
unhealthy social relationships, provoked anger of the victims of aggressive behavior, as well as being a model for other people's behavior. People who have aggressive behavior do the perception of the behavior that they do. They have a view of what they have done. Not only against his own behavior, yet the perpetrators of aggression also have the perception of other people's behavior.

Andi Hamzah stated (2009: 253) theft with violence is theft preceded, accompanied, or followed by violence or using threats of violence against people. Theft with violence is regulated in Article 365 of the criminal code which mentions:

1. Shall be punished by a maximum imprisonment of nine years of theft that proceeded, accompanied by, or followed by violence or threat of violence against a person with the intention of prepare for or facilitate the theft, or in this case being caught red-handed, to allow the escape of himself or other participants, or to remain the master of the stolen items.

2. Shall be punished by a maximum imprisonment of twelve years:

a. If the act is committed at night in a house or yard closed; in a run;

b. If the act committed by two or more people with the alliance;

c. If entry to the place to commit a crime by breaking or climbing or by using a false key, false order or false posture;

d. If the act results in serious injuries;

e. If the act results in death, then shall be punished by a maximum imprisonment of fifteen years.

3. Shall be punished with death penalty or life imprisonment or a maximum period of twenty years, if the act results in serious injuries or death and carried out by two or more people in an alliance, accompanied by one of the things that are explained in terms of number one and number three.

To achieve the intended result in this case to steal, then the maker commits violence or threatens violence. Theft with violence is not a combined theft in terms of the joints between the criminal offense of theft by criminal acts of violence even though it is committed with the violence, the violence in this case is the state of qualified, meaning that violence is a state that transforms the qualifications of ordinary theft into the theft with violence. If we looking at the sentence of the theft with violence, it can be concluded that in committing theft the perpetrator not only took other people's belongings yet also committed violence against the owner or the people involved when the perpetrators perform their action.

Based on the results of interviews with the perpetrators of criminal acts of theft accompanied by violence, it can be concluded that in committing theft, the perpetrator not only 
took other people's belongings yet also committed violence against the owner or related people/victims. Theft with violence itself is also often used sharp weapons in carrying out its action to make the victims feel afraid or threaten. Especially in the City of Surabaya, the perpetrators of the violent theft using a sharp weapon have been very unsettling to the society, they act not knowing the time and place.

\section{METHOD}

The method used in this research was a qualitative research method using a phenomenological approach. A phenomenological approach is a thinking view that emphasizes the experience-the subjective experience of the human being and its interpretation. This approach seeks to enter into the world of conceptual of the subject being researched in a such way that it can obtain an understanding of what and how the understanding is developed by them on events in the everyday life (Moleong, 2014). This research used data collection techniques of observation and interview. According to Bogdan and Biklen (in Moleong, 2014) qualitative data analysis is an effort made by working with data, organizing the data, sorting the data into units that can be managed, synthesizing them, looking for and finding the patterns, finding what is important and what is learned, and decide what to tell the others.

\section{RESULTS AND DISCUSSIONS}

This research took place from November 2020 until December 2020 at the Wonocolo Sector Police Detention Center in Surabaya. The characteristics of the informants were recorded as the perpetrators of a criminal acts of theft accompanied by violence. Interviews were conducted once in a week and each meeting conducted interviews for \pm 2 hours. Based on the results of interviews and observations that conducted by the researchers, the perpetrator of criminal acted of theft accompanied by violence showed that in committing theft, the perpetrator did not only take other people's belongings, but also committed violence against the owners or related persons/victims. The perpetrators were committing theft also often use a sharp weapon in implementing its action to make victim feel threatened. Especially in the City of Surabaya, the perpetrators committed their crime with violence by using a sharp weapon has been very unsettling to the society, they have acted irrespective of time and place.

According to the theory of typological, the criminal act of theft accompanied by violence committed by the perpetrators, in criminology has developed four theories called the typological or bio-typologies theories. The fourth flow has a similarity of thoughts and 
methodologies. They have the assumption or hypothesis that there is a difference between a bad person and a non-evil person. One of the theories of typology is the Theory of Psychiatric.

The theory of psychiatric is advanced or continuation theory of Lombroso without any changes in the view in morphological characteristics (Made Darma Vedas, 1996: 19) that this theory emphasizes more on the elements of psychological, epilepsy and moral insanity as the causes of crime. The theory of psychiatric gives significance to the emotional chaos, which shall be deemed to arise in social interaction and not by inheritance. The point of this theory is the particular organization of the personality of the person, which is developing far apart from the influence of evil, yet it still produces the behavior of evil regardless considering the situation of the social situation."

They committed a criminal act of theft accompanied by violence using sharp weapons under the reason that perpetrators felt confident when victims fought back or shouted for help from others. The underlying factors that cause theft with violence using a sharp weapon is as follows: 1). Low economic factors, 2). Low educational level factors, 3). Bad environmental factors, for example there are two environmental factors, namely the environmental factor of the perpetrator's family and the environmental factor of the perpetrator's association. Both of these two factors are equally play an important role in determining the mental and behavior of a person. A child who is taught a good behavior in his family yet that child associates with a lawbreaker, such as the drunken, is likely to commit the same action of violation with a friend they hang with or his associates. Sutherland invented the term different association to explain the process of learning criminal behavior through these social interactions.

According to Topo Santoso (2003: 74) the emergence of the theory of the Association of Differential by Sutherland is based on the nine propositions, namely: a). Criminal behavior is learned, b). Criminal behavior is studied in interaction with other persons in a process of the community, c). The most important part of studying criminal behavior can occurs within groups of people intimate/close people, d). When criminal behavior is studied, the learning that includes techniques of committing the crime, which are sometimes difficult, sometimes very easy and the specific directions of motives, impulses, rationalizations and attitudes, e). A specific direction of motives, that are studied through the definitions of the legal rules-the rule of law whether it is beneficial or not, f). A person becomes delinquent because of the definitions favorable to breaking the law are more than the definitions unfavorable to violation of the law, g). The association of differential may vary depending on the frequency, duration, priority and intensity, h). The process of studying criminal behavior through association with the patterns of the criminal and the meaning of the crime involves all the mechanisms that exist in every 
other study, i). Although criminal behavior is an expression of these common needs and values of the public, the non-criminal is also an expression of the same needs and values. 4). The last factor is the weak law enforcement factor.

The perpetrators also explained that the crimes they committed were based on the demands of the economic because of the influence of lifestyle in their environment. The economy is one of the important things in human life, thus the state of the economic condition of the perpetrators of criminal acts that often emerges as the background for someone to commit a criminal act of theft. The perpetrators often did not have a permanent job, or even do not have a job. Due to the economic pressure, which they must filled the needs of their family, buying clothes and food, or even some relatives are sick, then someone can do a reckless thing by committing a criminal act of theft.

The love for their family could made them forgot themselves and would do anything for the sake of happiness of their family. Moreover, if the driving factor is overcome with a sense of anxiety, worries, and so forth, due to the parents (generally mothers who have been a widow), the wives or the child or children, are seriously ill. They require medication, while money is difficult to get. Therefore, the perpetrators can be motivated to commit theft. See the development of the economic currently, it cannot be denied that the level of human needs is increasing so that it requires or demand high spending. However, sometimes the high demands for spending are not matched by high income as well. Finally, to fulfill their needs, some people sometimes justify any means.

Based on the results of interviews that conducted by the researchers on the perpetrators of the theft with violence used a sharp weapon, the researchers divided the economic factors into 2 (two) parts, namely economic factors to fulfill their needs of life and economic factors that are used for fun or leisure. Economic factors to fulfill their needs cannot be equated with economic factors that are only for pleasure, because both are used in the different ways. These factors that researchers pointed out because in accordance with the results of the interviews the researchers to some of the inmate's case of theft with violence in the big city Wonocolo Sector Police of Surabaya, the calculation of the income of the perpetrators of accumulating the amount of income from the two inmates who have been interviewed, where the income level was divided into 3 namely low, medium, and high. Levels of low income, namely $<\mathrm{Rp}$. $250.000 /$ month is taken as the basic levels of where the figure is approaching the figure of the lowest income of the two prisoners who were interviewed, namely Rp.200,000/month, while the high-income level is $>$ Rp.500,000/month, where the income is approaching the figure of 
the highest income of the two prisoners who were interviewed namely Rp.800.000/month. Here are the following results of the data that the researchers illustrated in the table:

Table 1. Income levels of the perpetrators of the theft with violence using a sharp weapon in the city of Surabaya 2020.

\begin{tabular}{|c|c|c|c|}
\hline No & Income The Perpetrators & Frequency & $\begin{array}{c}\text { Percentage } \\
\%\end{array}$ \\
\hline 1. & Low $(\leq 250.000)$ & 1 & $50 \%$ \\
\hline 2. & Medium (251.000-500.000) & 0 & $0 \%$ \\
\hline 3. & High $(\geq 551.000)$ & 1 & $50 \%$ \\
\hline & Total & 2 & $100 \%$ \\
\hline
\end{tabular}

Source: Polrestabes Surabaya, December 2020

\section{CONCLUSION}

Based on the analysis of the results of research on the Dynamics of psychological perpetrators of criminal acts of theft accompanied by violence at the Wonocolo Sector Police Detention Center in Surabaya, thus the result show that the perpetrators not only took other people's belongings, yet also committed violence against the owners or related persons/victims. The perpetrators in committing the theft also often use a sharp weapon in implementing their action to make the victims feel afraid. They are committing a criminal act of theft accompanied by violence use a sharp weapon under the reason so that the perpetrators feel confident when the victims resist or scream for help from others. The two main factors that made the perpetrators committing a criminal act of theft accompanied by violence are bad environmental factors and low economic factors.

\section{REFERENCES}

Andi Hamzah. (2009). Special Delicten in the Criminal Code. Sinar Grafika: Jakarta.

Atkinson, Richard C. (2001). Introduction to Psychology. Jakarta: Interaksa.

Baron, R. A. \& Byrne, D. (2003). Social Psychology. Boston: Allyn \& Bacon.

Faturochman, \& Ancok, D. (2001). "Psychological Dynamics of Justice Assessment". Journal of Psychology. (1), 41-60 Krahe, B. (2005). Aggressive Behavior. Yogyakarta: Pustaka Pelajar.

Gibson, et al. (1996). Organizational Behavior, Structure and Process. Jakarta: Binarupa Aksara.

Koeswara, E. (1988). Human Aggression. Bandung: PT Eresco Lemmens, J.S, et al. 2009. "Development and Validation of a Game Addiction Scale for Adolescents". Media 
Psychology. (12): 77-95 Margaretha. (2013). Child Crime. [Online]. Available: http://psikologiforensik.com/tag/kejahatan-anak/ [January $\left.1^{\text {st }} 2015\right]$.

Koeswara, E. (1988). Human Aggression. Bandung: PT Erasco.

Krahe, B. (2005). Aggressive Behavior. Yogyakarta: Pustaka Pelajar.

Moleong, L.J. (2014). Qualitative Research Methods. Bandung. PT.Remaja Rosdakarya.

Fitriani, Asih. (2012). The Behavior of Foster Children (Case Studies of Adolescents in Orphanages Islamic "Ibadah Bunda" Yogyakarta).

Kreitnern dan Kinicki. (2005). Organizational behavior, Book 1. Jakarta :Salemba Empat.

Rofiq, Nur Baety. (2013). http:// akarpadinews. com/ read/ entertainment / people- Indonesian94- percent- watching- $t v$ accessed on February $17^{\text {th }} 2015$.

Shiddiqah, L. (2010). Prevention and Handling of Adolescent Aggressive Behavior through (Anger Management). Journal of Psychology. 37, (1): 50-64.

Soesilo, R. (1996). Criminal Code. Politeia: Jakarta.

Topo santoso. (2003). Criminology. Raja Grafindo Persada: Jakarta.

Weda, Made Darma. (1996). Criminology. Raja Grafindo Persada: Jakarta. 